\title{
Obtención de una adición puzolánica a partir de la calcinación controlada de lodos de destintado de papel: estudio de prestaciones en matrices de cemento
}

\author{
Obtaining a pozzolanic addition from the controlled calcination \\ of paper mill sludge. Performance in cement matrices
}

\author{
${\underline{\text { I. } \operatorname{Vegas}^{(*)}}}$, M. Frías $(* *)$, J. Urreta(*), J. T. San José(*), (***)
}

Recepción/Received: 12-IX-05

Aceptación/Accepted: 13-III-06

\section{RESUMEN}

Los lodos de destintado del papel están constituidos, mineralógicamente, por calcita, caolinita, talco y otros filosilicatos (ilita, clorita). Cuando al lodo se le somete a un tratamiento térmico controlado, la caolinita puede transformarse en metacaolín, dando origen a un producto de alta reactividad puzolánica.

El objeto de este trabajo es analizar diferentes aspectos científicos relativos al proceso de obtención de una adición puzolánica a partir de la activación térmica controlada de lodos de destintado del papel, así como evaluar el comportamiento de la nueva adición cuando se incorpora en una matriz de cemento. Los resultados obtenidos ponen de manifiesto la recomendación de utilizar $700{ }^{\circ} \mathrm{C}$ durante 2 horas de permanencia en el horno, como condiciones más óptimas para activar los residuos de lodos de papel en el intervalo $700-800{ }^{\circ} \mathrm{C}$. Del estudio comparativo del cemento elaborado con la nueva adición con respecto a un cemento comercial (CEM I-42,5R), se puede destacar la viabilidad científica y técnica de este residuo como material cementante secundario.

Palabras clave: lodos de destintado del papel, adición activa, metacaolín, cemento con adiciones, propiedades del cemento.

\section{SUMMARY}

Mineralogically, the paper mill sludge consists essentially of calcite, kaolinite, talc and other philosilicates (illite, chlorite). When such sludge is subjected to controlled thermal treatment, its kaolinite component may be transformed into metakaolin, yielding a product with high pozzolanic reactivity.

This study was designed to analyze a number of scientific questions around the production of pozzolanic additions via controlled thermal activation of paper mill sludge and to evaluate the performance of such additions when included in a cement matrix. The findings show that paper mill waste activation is optimal when the sludge is calcined for 2 hours at $700{ }^{\circ} \mathrm{C}$ in the $700-800{ }^{\circ} \mathrm{C}$ intervale. A comparative study between the cement made with the new addition and a commercial cement (CEM I-42.5R) used as a reference led to highlight the scientific and technical viability of this waste as a cementing seconding material.

Keywords: paper de-inking sludge, active addition, metakaolin, cement with additions, cement properties.

(*) LABEIN-Tecnalia, Derio (España).

(**) Instituto de Ciencias de la Construcción Eduardo Torroja (IETcc-CSIC), Madrid (España).

(***) UPV-EHU, Bilbao (España). 


\section{INTRODUCCIÓN}

Durante las últimas décadas, en consonancia con las nuevas políticas de desarrollo sostenible, la industria cementera viene utilizando diferentes subproductos industriales (cenizas volantes, humo de sílice y escorias de procesos siderúrgicos, principalmente) como adición activa en la elaboración de cementos comerciales. Semejante práctica obedece, principalmente, a la necesidad de conciliar aspectos medioambientales inherentes a la producción de clínker (reducción de impactos asociados a emisiones de $\mathrm{CO}_{2}$ y explotación de recursos naturales) con aspectos puramente financieros y de mercado (1). Asimismo, el hecho de utilizar adiciones reporta otro tipo de beneficios de índole científico, técnico y económico tales como la mejora de las prestaciones mecánicas y durabilidad del cemento, así como la reducción de consumos energéticos asociados al proceso de clinkerización (2-4).

Ante una coyuntura como la descrita, no es de extrañar que en la actualidad continúen abriéndose líneas de investigación dirigidas a obtener nuevas adiciones puzolánicas a partir de subproductos industriales diferentes a los tradicionalmente utilizados por la industria cementera. En este sentido, una de las líneas de investigación más recientes se centra en el estudio de adiciones activas a partir de la calcinación controlada de lodos de destintado procedentes de procesos de fabricación de papel que utilizan, como materia prima, papel reciclado. Los trabajos pioneros en este campo se deben a Pera et al. (5-8). Este equipo de investigadores demostró que la calcinación de lodos de destintado a temperaturas por debajo de $750{ }^{\circ} \mathrm{C}$ produce un material puzolánico altamente reactivo. El contenido de materia orgánica (celulosa) presente en los lodos secos analizados oscilaba entre un $23,8 \%$ y un $54,2 \%$. El contenido de compuestos inorgánicos (caolinita, moscovita, talco, carbonato cálcico, dióxido de titanio y cuarzo), procedentes de cargas utilizadas para el acabado superficial y blancura del papel, variaba entre un $44,4 \%$ y un $75,4 \%$. Asimismo, analizaron la influencia del lodo calcinado en matrices cementicias. Para mezclas que contenían un $80 \%$ de un cemento Portland convencional y un $20 \%$ del lodo calcinado, evidenciaron una ligera mejora en las resistencias a compresión (superior al 10\% de la resistencia a compresión obtenida a 7 y 28 días para matrices cementicias elaboradas con un $100 \%$ del cemento utilizado como conglomerante de referencia), así como una disminución del $30 \%$ en el diámetro medio de poro.

Actualmente, sobre la base del conocimiento científico expuesto anteriormente, un equipo de investigadores españoles, liderados por M. Frías (9-10), está profundizando en aspectos científicos, tecnológicos y medioambientales acerca de la obtención de adiciones activas a partir de la calcinación de lodos de destintado y de las prestaciones de éstas en mezclas de cementos.

\section{INTRODUCTION}

In the wake of the sustainable development policies implemented in the last few decades, the cement industry has been using different industrial by-products (primarily fly ash, silica fume and blast furnace slag) as active additions in the manufacture of commercial cements. This practice is essentially a response to the need to reconcile the environmental issues inherent in clinker production ( $\mathrm{CO}_{2}$ emissions and the over-exploitation of natural resources) with purely financial and market considerations (1). Moreover, the use of additions involves other types of benefits of a scientific, technical and economic nature, such as improvements in cement mechanical performance and durability and the reduction of the energy costs associated with clinkerization (2-4).

It is hardly surprising in such a scenario that new lines of research should appear, geared to obtaining pozzolanic additions from industrial by-products other than those traditionally used by the cement industry. In this regard, one of the most recent approaches focuses on the study of active additions obtained from the controlled calcination of sludge from paper mills using recycled paper as a prime material. Pera et al. (5-8) pioneered such studies. That research team showed that the calcination of paper mill sludge at temperatures of under $750^{\circ} \mathrm{C}$ yields a highly reactive pozzolanic material. They reported that the organic matter (cellulose) content present in the dry sludge analyzed ranged from 23.8 to $54.2 \%$ and found the inorganic content (kaolinite, muscovite, talc, calcium carbonate, titanium dioxide and quartz) generated by the processes involved in paper bleaching and surface finishing to range from 44.4 to $75.4 \%$. An analysis of the effect of calcined sludge on cementitious matrices showed a slight improvement in compressive strength in mixes with $80 \%$ conventional Portland cement and $20 \%$ calcined sludge (10\% higher compressive strength at 7 and 28 days than cement matrices made with $100 \%$ of the cement used as the reference binder), as well as a $30 \%$ decline in mean pore diameter.

A Spanish research team under the leadership of $M$. Frías (9-10) is presently expanding on the above knowledge to explore the scientific, technological and environmental issues entailed in obtaining active additions from calcined paper mill sludge, and the performance of this material in blended cement. 
Esta línea de investigación resulta de especial interés en España dado que contribuiría a mejorar la competitividad de determinados fabricantes de papel y de la industria cementera. La generación de lodos de destintado en España se estima en torno a las 400.000 toneladas/año (11). A partir de la valorización de dichos lodos, se podrían obtener unas 150.000 toneladas/año de un nuevo material puzolánico potencialmente utilizable en la elaboración de cementos. La transferencia a la industria de los resultados de esta línea de investigación favorecería significativamente la reducción de costes e impactos asociados al vertido de los lodos de destintado, a la extracción de recursos minerales naturales en el proceso de fabricación de cemento, así como a emisiones de $\mathrm{CO}_{2}$.

\section{MATERIALES Y PARTE EXPERIMENTAL}

\subsection{Materiales}

El material de partida utilizado en el presente trabajo fue un lodo de destintado generado por la empresa Holmen Paper/Papelera Peninsular, S.L. en la etapa de destintado del papel reciclado, utilizado como materia prima.

La Tabla 1 muestra la composición química y mineralógica de dicho lodo de partida. La determinación química de los materiales de partida se llevó a cabo mediante la técnica de fluorescencia de rayos $\mathrm{X}$. El aparato utilizado ha sido un espectrómetro secuencial de FRX, PW 2404 Philips. La composición mineralógica de los lodos se determinó mediante difracción de rayos X. Para la caracterización del lodo inicial se utilizó el método de polvo desorientado y para la comprobación de la naturaleza de los filosilicatos constituyentes se utiliza el método de agregado orientado. El porcentaje de los diferentes minerales de la muestra se calculó mediante la relación entre las áreas de los picos característicos a partir del difractograma de polvo desorientado y agregado orientado. La cuantificación de los componentes se realizó siguiendo el método de los poderes reflectantes (12-13). En el difractograma de polvo desorientado se midieron las áreas correspondientes a filosilicatos $(4,45-4,50 \AA)$, cuarzo $(4,26 \AA)$ y calcita $(3,04 \AA)$. En el agregado orientado las correspondientes a los filosilicatos siguientes: talco $(9,40 \AA)$; caolinita $(7,15 \AA)$ y mica $(9,95-10,01 \AA)$ (14). Las áreas de los picos se determinaron mediante el ajuste a una gaussiana y sustracción de la línea base. Este procedimiento se realizó utilizando un programa matemático convencional.

El análisis mineralógico del lodo de partida revela un contenido significativo de caolinita $(20,83 \%)$, principal precursor de metacaolín reactivo bajo determinadas condiciones de temperatura y mantenimiento en horno (15). De
This line of research is of particular interest in Spain because it would contribute to the competitiveness of certain paper manufacturers as well as the country's cement industry. Spain is estimated to generate on the order of 400,000 tonnes of paper mill sludge per year (11). Recycling all this sludge would yield around 150,000 tonnes/year of a new pozzolanic material potentially usable in cement manufacture. The transfer of technology stemming from this line of research would significantly lower the costs of paper mill sludge disposal and the impact of mineral extraction for cement manufacture and $\mathrm{CO}_{2}$ emissions.

\section{MATERIALS AND EXPERIMENTAL}

\subsection{Materials}

The base material used in the present study was paper sludge generated by Holmen Paper/Papelera Peninsular, S.L. during the bleaching of the recycled paper used as a prime material.

Table 1 gives the chemical and mineralogical composition of the sludge used. The chemistry of the base materials was determined with $X$-ray fluorescence, using a Philips PW 2404 sequential XRF spectrometer. The mineralogical composition of the sludge was studied with X-ray diffraction techniques. The initial sludge was characterized using the unoriented powder method, while the oriented aggregate method was used to identify the constituent philosilicates. The percentage composition of the sample was calculated from the ratio between the areas under the characteristic peaks on the unoriented powder and oriented aggregate diffractograms. The components were quantified with the reflecting powers method (1213). The areas for the philosilicates (4.45 - $4.50 \AA)$, quartz (4.26 $\AA$ ) and calcite $(3.04 \AA)$ were measured on the unoriented powder traces, while the areas for the other philosilicates: talc (9.40 A); kaolinite (7.15 $\AA$ ) and mica (9.95 - $10.01 \AA$ ) (14) were taken from the oriented aggregate patterns. Conventional mathematical software was used to fit the peaks to a Gaussian curve and subtract the baseline, thereby determining their areas.

The mineralogical analysis of the initial sludge revealed a significant kaolinite content (20.83\%). This mineral is the main precursor of reactive metakaolin under certain temperature and kiln time conditions (15). According to 
acuerdo al modelo de regresión lineal múltiple propuesto por Pera et al. (5), a mayor contenido de caolinita en el lodo de partida, mayor actividad puzolánica en el producto calcinado.

Para el estudio de las propiedades mecánicas, físicas y químicas se utilizaron dos tipos de cemento:

- Cemento P: un cemento Portland comercial CEM I 42,5R que sirvió de patrón comparativo. Se seleccionó un cemento Portland con un porcentaje en clínker lo más cercano al $100 \%$. La composición química y mineralógica del clínker se presenta en la Tabla 2.

- Cemento M: un cemento obtenido por mezcla de un $90 \%$ (en masa) del cemento P con un $10 \%$ (en masa) del lodo calcinado.

\subsection{Calcinación de lodos}

El lodo de destintado seco de partida fue sometido a un proceso de calcinación según las condiciones recogidas en la Tabla 3. Posteriormente, se molió el producto calcinado para obtener un tamaño de partícula inferior a 45 micras.

\subsection{Determinación de la actividad puzolánica}

El estudio de la actividad puzolánica de los lodos calcinados se realizó por medio de un método de análisis acelerado. El ensayo consistió en poner en contacto los lodos calcinados con una disolución saturada de cal a $40{ }^{\circ} \mathrm{C}$, durante distintos periodos de tiempo. Al final de cada periodo, se analizó la concentración de $\mathrm{CaO}$ en disolución. La cal fijada ( $\mathrm{mmol} / \mathrm{L}$ ) se obtuvo por diferencia entre la concentración del ensayo de referencia y el $\mathrm{CaO}$ analizado de la solución en contacto con la muestra. the multiple linear regression model proposed by Pera et al. (5), the higher the kaolinite content in the initial sludge, the higher is the pozzolanic activity in the calcined product.

The mechanical, physical and chemical properties of two types of cement were studied:

- Cement P: a commercial Portland cement, CEM I 42.5R, used as a standard for comparison. A Portland cement with a clinker content as close as possible to $100 \%$ was chosen. Clinker chemical and mineralogical composition is given in Table 2.

- Cement M: a cement obtained by mixing 90\% (by mass) of cement $P$ with $10 \%$ (by mass) of calcined sludge.

\subsection{Sludge calcination}

The initial dry paper mill sludge was calcined as described in Table 3. The calcined product was subsequently ground to a particle size of under 45 microns.

\subsection{Description of pozzolanic activity}

The pozzolanic activity of the calcined sludge was studied using the accelerated analysis method. This test consisted in storing the calcined sludge in a lime-saturated solution at $40{ }^{\circ} \mathrm{C}$ for different periods of time. The $\mathrm{CaO}$ concentration in the solution was analyzed at the end of each period. The lime fixed $(\mathrm{mmol} / \mathrm{l})$ was found as the difference between the initial concentration and the $\mathrm{CaO}$ content in the solution in contact with the sample.

Tabla 1 / Table 1

Características de los lodos de partida

Initial sludge characteristics

\begin{tabular}{|c|c|c|c|}
\hline \multicolumn{2}{|c|}{$\begin{array}{l}\text { Composición química ( } \% \text { en masa) } \\
\text { Chemical composition ( } \% \text { by mass) }\end{array}$} & \multicolumn{2}{|c|}{$\begin{array}{l}\text { Composición mineralógica y materia orgánica ( } \% \text { en masa) } \\
\text { Mineralogical composition and organic matter (\% by mass) }\end{array}$} \\
\hline Pérdida por calcinación / Loss of ignition & 47.62 & Materia Orgánica / Organic matter & 29.20 \\
\hline $\mathrm{CaO}$ & 19.82 & Calcita / Calcite & 35.30 \\
\hline $\mathrm{SiO}_{2}$ & 18.01 & Caolinita / Kaolinite & 20.83 \\
\hline $\mathrm{Al}_{2} \mathrm{O}_{3}$ & 10.14 & Talco / Talc & 6.85 \\
\hline $\mathrm{MgO}$ & 2.58 & Cuarzo / Quartz & 1.71 \\
\hline $\mathrm{Fe}_{2} \mathrm{O}_{3}$ & 0.55 & \multirow{6}{*}{$\begin{array}{l}\text { Componentes minoritarios (clorita, micas...) } \\
\text { Minority components (chlorite, micas...) }\end{array}$} & \multirow[t]{2}{*}{1.71} \\
\hline $\mathrm{SO}_{3}$ & 0.33 & & \\
\hline $\mathrm{Na}_{2} \mathrm{O}$ & 0.25 & & \\
\hline $\mathrm{TiO}_{2}$ & 0.26 & & \\
\hline $\mathrm{K}_{2} \mathrm{O}$ & 0.21 & & \\
\hline $\mathrm{P}_{2} \mathrm{O}_{5}$ & 0.10 & & \\
\hline
\end{tabular}


Tabla 2 / Table 2

Composición química y mineralógica del clínker de cemento utilizado en los cementos $\mathrm{P}$ y $\mathrm{M}$

Chemical and mineralogical composition of the clinker used in cements $P$ and $M$

\begin{tabular}{|c|c|c|c|}
\hline \multicolumn{2}{|c|}{$\begin{array}{l}\text { Composición química ( } \% \text { en masa) } \\
\text { Chemical composition ( } \% \text { by mass) }\end{array}$} & \multicolumn{2}{|c|}{$\begin{array}{l}\text { Composición mineralógica ( } \% \text { en masa) } \\
\text { Mineralogical composition ( } \% \text { by mass) }\end{array}$} \\
\hline $\mathrm{CaO}$ total / Total $\mathrm{CaO}$ & 65.6 & $\mathrm{C}_{3} \mathrm{~S}$ & 65.29 \\
\hline $\mathrm{SiO}_{2}$ & 20.71 & $\mathrm{C}_{2} \mathrm{~S}$ & 10.21 \\
\hline $\mathrm{Al}_{2} \mathrm{O}_{3}$ & 5.58 & $\mathrm{C}_{3} \mathrm{~A}$ & 9.24 \\
\hline $\mathrm{Fe}_{2} \mathrm{O}_{3}$ & 3.28 & $\mathrm{C}_{4} \mathrm{AF}$ & 9.97 \\
\hline $\mathrm{MgO}$ & 1.05 & & \\
\hline CaO libre / Free $\mathrm{CaO}$ & 0.52 & & \\
\hline
\end{tabular}

Tabla 3 / Table 3

Condiciones de calcinación

Calcination conditions

\begin{tabular}{|ccc|}
\hline $\begin{array}{c}\text { Identificación del lodo calcinado } \\
\text { Calcined paper sludge sample }\end{array}$ & $\begin{array}{c}\text { Temperatura }\left({ }^{\circ} \mathrm{C}\right) \\
\text { Temperature }\left({ }^{\circ} \mathrm{C}\right)\end{array}$ & $\begin{array}{c}\text { Permanencia en horno (horas) } \\
\text { Kiln time (hours) }\end{array}$ \\
\hline LPC 1 & 700 & 2 \\
\hline LPC 2 & 700 & 5 \\
\hline LPC 3 & 750 & 2 \\
\hline LPC 4 & 750 & 5 \\
\hline LPC 5 & 800 & 2 \\
\hline
\end{tabular}

\subsection{Estudio de las propiedades macroscópicas de la mezcla de cemento con el lodo calcinado}

El estudio de propiedades macroscópicas se articuló en torno a las especificaciones y criterios de conformidad establecidas en la UNE-EN 197-1-Parte 1 (16).

Para los dos cementos objeto de estudio ( $P$ y $M$ ) se determinaron resistencias mecánicas a diferentes edades de acuerdo a la norma UNE-EN 196-1, estabilidad en volumen y tiempos de fraguado de acuerdo a la norma UNE-EN 196-3, así como contenido en $\mathrm{SO}_{3}$, pérdida por calcinación y contenido en cloruros de acuerdo a las normas UNE-EN 196-2 y UNE-EN 196-21. Para cada una de las propiedades analizadas se realizó el estudio comparativo entre el cemento comercial $\mathrm{P}$ y el cemento $\mathrm{M}$ con la nueva adición.

\section{RESULTADOS Y DISCUSIÓN}

\subsection{Actividad puzolánica}

La Figura 1 recoge los valores de cal fijada por los diferentes productos calcinados con el tiempo de reacción. Se puede observar que todos los lodos calcinados evidencian una alta actividad puzolánica en los primeros días de reacción, si bien presentan diferencias significativas

\subsection{Study of the macroscopic properties of the cement blended with calcined sludge}

Macroscopic properties were established to the specifications and conformity criteria laid down in Spanish/European standard UNE-EN 197-1- Part 1 (16).

The mechanical strength of the two cements studied ( $P$ and M) was found at different ages as per Spanish/European standard UNE-EN 196-1, volume stability and setting times as per UNE-EN 196-3, and $\mathrm{SO}_{3}$ content, loss on ignition and chloride content as per standards UNEEN 196-2 and UNE-EN 196-21. A comparative study was conducted between commercial cement $P$ and new addition-containing cement $M$ for all the properties analyzed.

\section{RESULTS AND DISCUSSION}

\subsection{Pozzolanic activity}

Figure 1 shows the amount of lime fixed by the different calcined products at each reaction time. Note that all the calcined sludge samples exhibited high pozzolanic activity in the first few days of the reaction, although significant differences were observed in the first 24 hours. 
durante las primeras 24 horas de reacción. La actividad puzolánica disminuye con el aumento de las condiciones de calcinación. Así, el LPC5 presenta menor actividad puzolánica. Cabe destacar, también para el LPC5, que durante las primeras 24 horas de reacción se detecta un valor negativo de la cantidad de cal fijada. Este hecho se debe a una sobresaturación de la disolución saturada de cal, debido al exceso de $\mathrm{CaO}$ procedente de la descarbonatación de la calcita a $800{ }^{\circ} \mathrm{C}$. De los resultados obtenidos, se puede poner de manifiesto que las condiciones más idóneas para la calcinación de estos residuos industriales, desde un análisis integrado de prestaciones técnicas, eficiencia energética de proceso y mejora de impactos medioambientales, es a $700^{\circ} \mathrm{C}$ y 2 horas de mantenimiento en horno para el intervalo estudiado entre 700 y $800{ }^{\circ} \mathrm{C}$. Consecuentemente, en torno al lodo calcinado denominado como LPC1 se articuló el estudio de los siguientes apartados:

\subsection{Caracterización química y mineralógica del producto más activo}

Sobre el producto calcinado a $700{ }^{\circ} \mathrm{C}$, durante 2 horas de permanencia en el horno, se realizó la caracterización química mediante fluorescencia de rayos $X(F R X)$, cuyos resultados analíticos se encuentran recogidos en la Tabla 4. Los valores revelan que, tal como ocurría con el lodo de papel de partida, el producto calcinado está constituido
Pozzolanic activity declined with increasing calcination conditions. Hence, the lowest pozzolanic activity was found for LPC5. This sample also showed a negative value for the amount of lime fixed in the first 24 hours due to supersaturation of the lime solution as a result of the excess $\mathrm{CaO}$ generated by calcite decarbonation at $800{ }^{\circ} \mathrm{C}$. Based on the results obtained and a comprehensive analysis of technical performance, process energy efficiency and lessening of environmental impact, the most effective conditions for activating this industrial waste (in the range studied, 700 to $800^{\circ} \mathrm{C}$ ) called for a kiln temperature of $700{ }^{\circ} \mathrm{C}$ and a calcination time of 2 hours. Consequently, the LPC1 calcined sludge was used to study the following properties:

\subsection{Chemical and mineralogical characterization of the most active product}

The product calcined at $700^{\circ} \mathrm{C}$ for 2 hours was chemically characterized with X-ray fluorescence (XRF). The results of this analysis given in Table 4 revealed that, like the initial paper sludge, the calcined product contained very similar proportions of silica and calcium (30.20\% and $31.40 \%$, respectively), followed by alumina

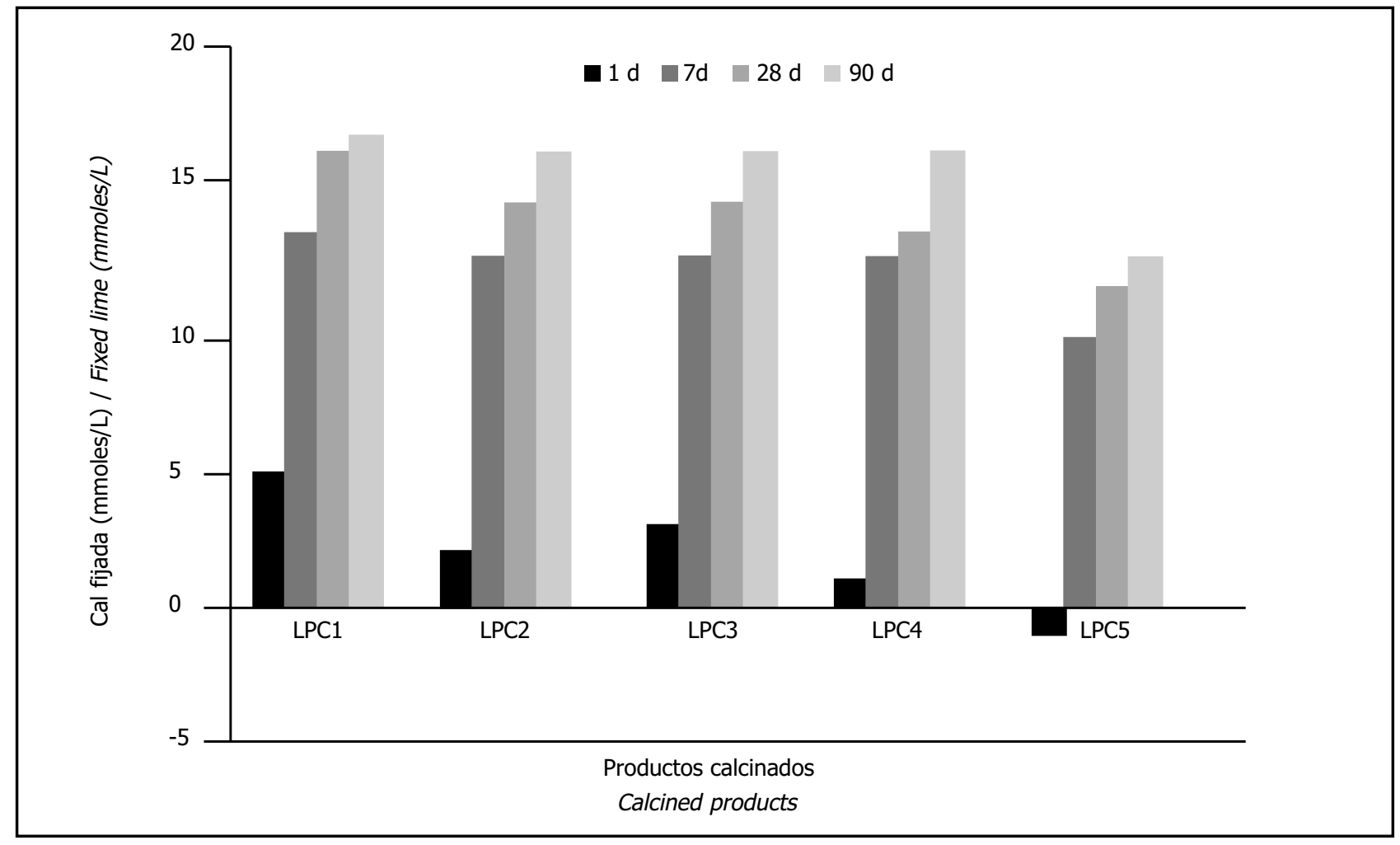

Figura 1. Actividad puzolánica de los lodos calcinados.

Figure 1. Pozzolanic activity of calcined paper sludge. 
por sílice y calcio en proporciones muy similares $(30,20 \%$ y $31,40 \%$ respectivamente), seguido por alúmina y magnesia. El resto de los óxidos no superan el $1 \%$.

El estudio morfológico del lodo calcinado se llevó a cabo mediante microscopía electrónica de barrido (MEBEDAX). La observación superficial pone de manifiesto una gran abundancia de calcio que recubre todos los compuestos junto con agregados de calcita con superficie muy porosa (Figuras 2 y 3), la formación de metacaolín con morfología pseudoexagonal (Figura 4), así como la presencia de talco con aspecto fibroso (Figura 5).

\subsection{Resistencias mecánicas}

La Tabla 5 presenta la evolución de resistencias a flexotracción. Los resultados evidencian resistencias a flexotracción del cemento $M$ ligeramente inferiores a las exhibidas por el cemento de referencia, a las diferentes edades ensayadas.

La Figura 6 muestra la evolución de las resistencias mecánicas a compresión durante los primeros 28 días de curado de los cementos $\mathrm{P}$ y $\mathrm{M}$. Estos resultados ponen de manifiesto dos evoluciones resistentes diferentes. Por un lado, a edades tempranas (de 1 a 3 días), el cemento $\mathrm{M}$ presenta resistencias a compresión ligeramente and magnesia. The proportion of all other oxides was under $1 \%$.

The morphology of the calcined sludge was studied with scanning electron microscopy (SEM-EDAX). The surface was observed to have large proportions of calcium covering all the other components, as well as superficially porous calcite clusters (Figures 2 and 3). Pseudohexagonal metakaolin (Figure 4), and fibrous talc (Figure 5) were likewise visible.

\subsection{Mechanical strength}

The flexural strength values are given in Table 5. According to these results, cement $M$ exhibited slightly lower flexural strength than the reference cement at the various ages tested.

Figure 6 shows the mechanical strength values for cements $P$ and $M$ over the first 28 days. The results revealed two different strength patterns. On the one hand, at early ages (from 1 to 3 days), cement $M$ had slightly lower compressive strength than the standard cement $(P)$, indicating that in this time interval, the effect of the

Tabla 4 / Table 4

Composición química de LPC1 (\% en masa)

Chemical composition of LPC1 (\% by mass)

\begin{tabular}{|cccccccccccc|}
\hline $\mathbf{C a O}$ & $\mathbf{S i O}_{\mathbf{2}}$ & $\mathbf{A l}_{\mathbf{2}} \mathbf{O}_{\mathbf{3}}$ & $\mathbf{P . ~ F}$. & $\mathbf{M g O}$ & $\mathbf{F e}_{\mathbf{2}} \mathbf{O}_{\mathbf{3}}$ & $\mathbf{T i O}_{\mathbf{2}}$ & $\mathbf{K}_{\mathbf{2}} \mathbf{O}$ & $\mathbf{S O}_{\mathbf{3}}$ & $\mathbf{N a}_{\mathbf{2}} \mathbf{O}$ & $\mathbf{P}_{\mathbf{2}} \mathbf{O}_{\mathbf{5}}$ & $\mathbf{M n}_{\mathbf{2}} \mathbf{O}_{\mathbf{3}}$ \\
\hline 31.40 & 30.20 & 18.00 & 14.53 & 3.70 & 0.70 & 0.35 & 0.32 & 0.27 & 0.21 & 0.19 & 0.02 \\
\hline
\end{tabular}

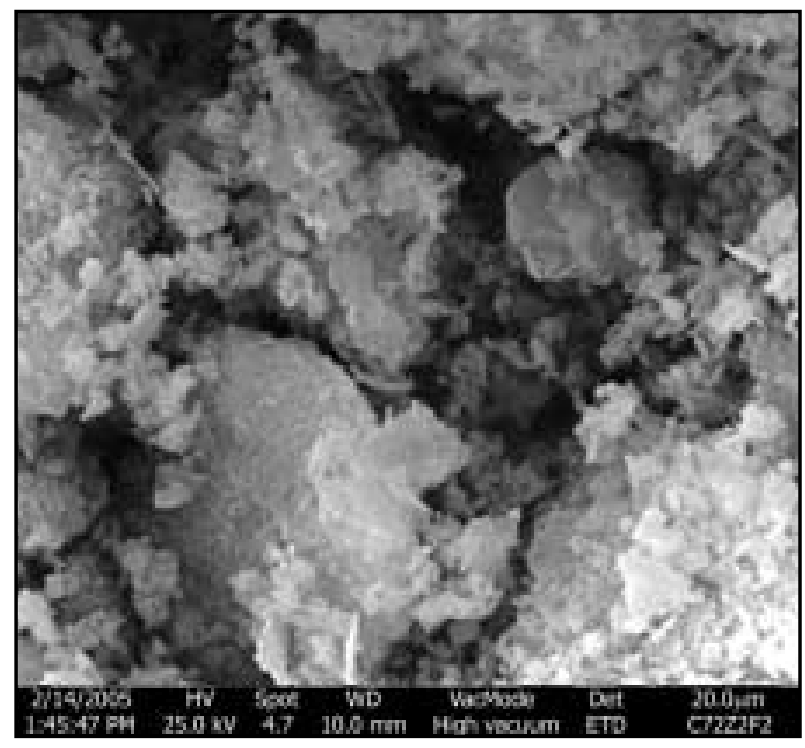

Figura 2. Agregados de calcita. Figure 2. Calcite clusters.

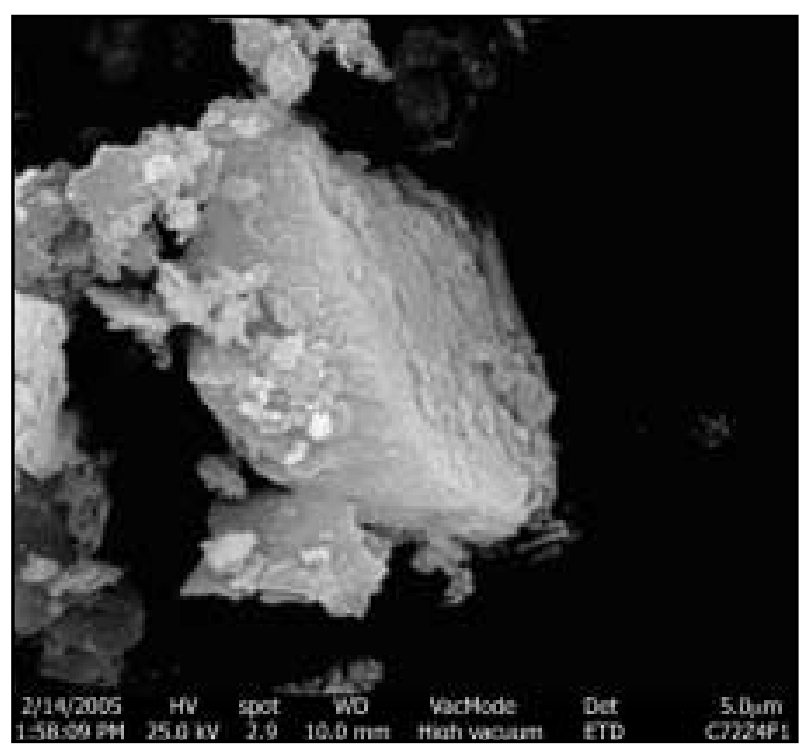

Figura 3. Detalle de cristal de calcita de morfología hexagonal. Figure 3. Detail of hexagonal calcite crystal. 


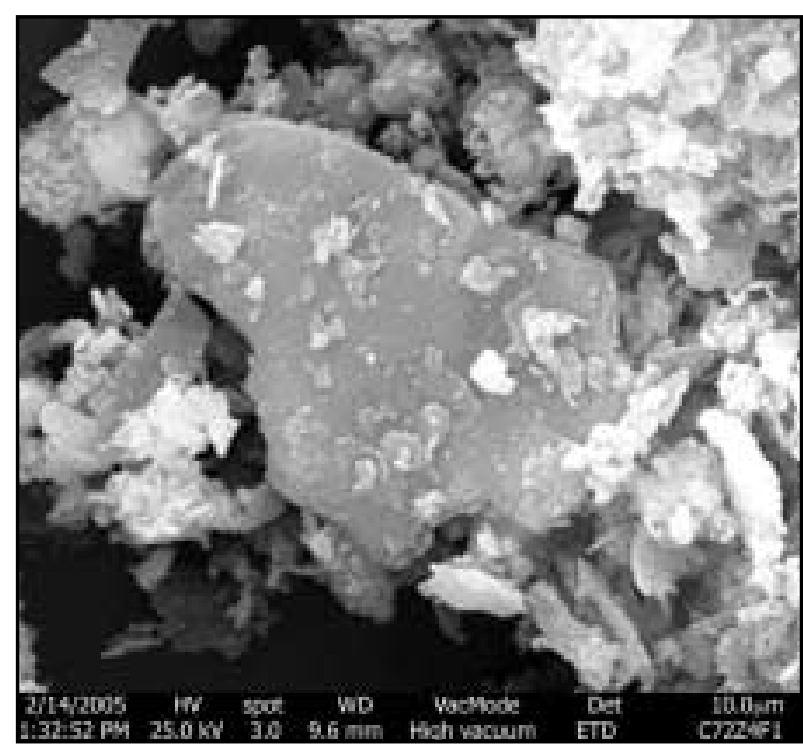

Figura 4. Cristal de morfología pseudohexagonal de metacaolinita. Figure 4. Pseudohexagonal metakaolin crystal.

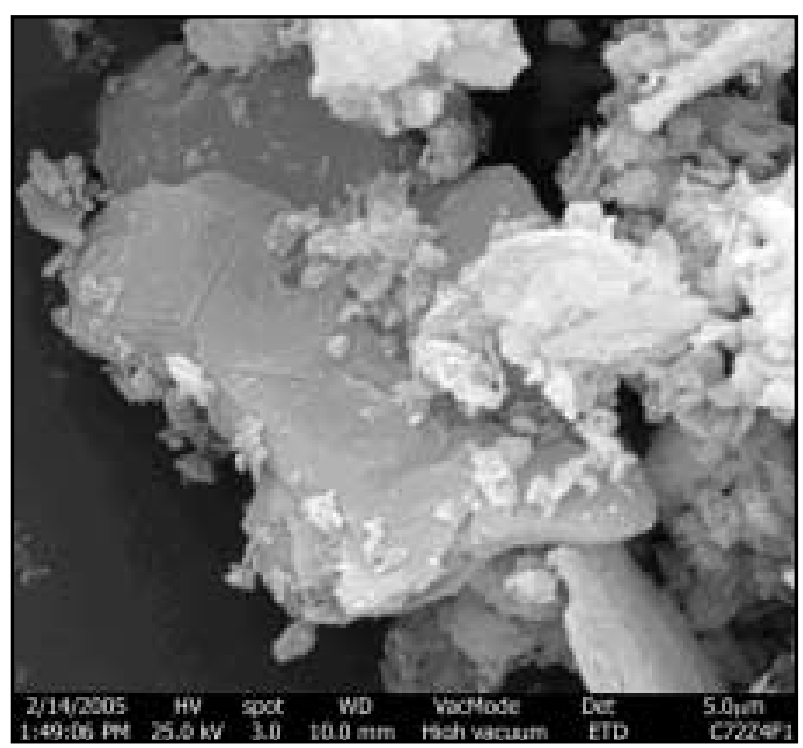

Figura 5. Detalle de talco fibroso recubierto de cristal de calcita. Figure 5. Detail of calcite crystals covering fibrous talc.

Tabla 5 / Table 5

Resistencias mecánicas a flexo-tracción de los cementos $\mathrm{P}$ y $\mathrm{M}$ Flexural strength of cements $P$ and $M$

\begin{tabular}{|l|ccccc|}
\hline $\begin{array}{l}\text { Tipo de cemento } \\
\text { Type of cement }\end{array}$ & \multicolumn{5}{|c|}{ Resistencias mecánicas a flexo-tracción (MPa) } \\
\hline & 1 día / 1 day & 3 días / 3 days & 7 días / 7 days & 14 días / 14 days & 28 días / 28 days \\
\hline Cemento P / Cement P & 5.77 & 7.36 & 8.26 & 8.21 & 8.58 \\
\hline Cemento M / Cement M & 5.09 & 7.12 & 7.71 & 7.57 & 7.85 \\
\hline
\end{tabular}

Evolución resistencias / Evolution of compressive strength

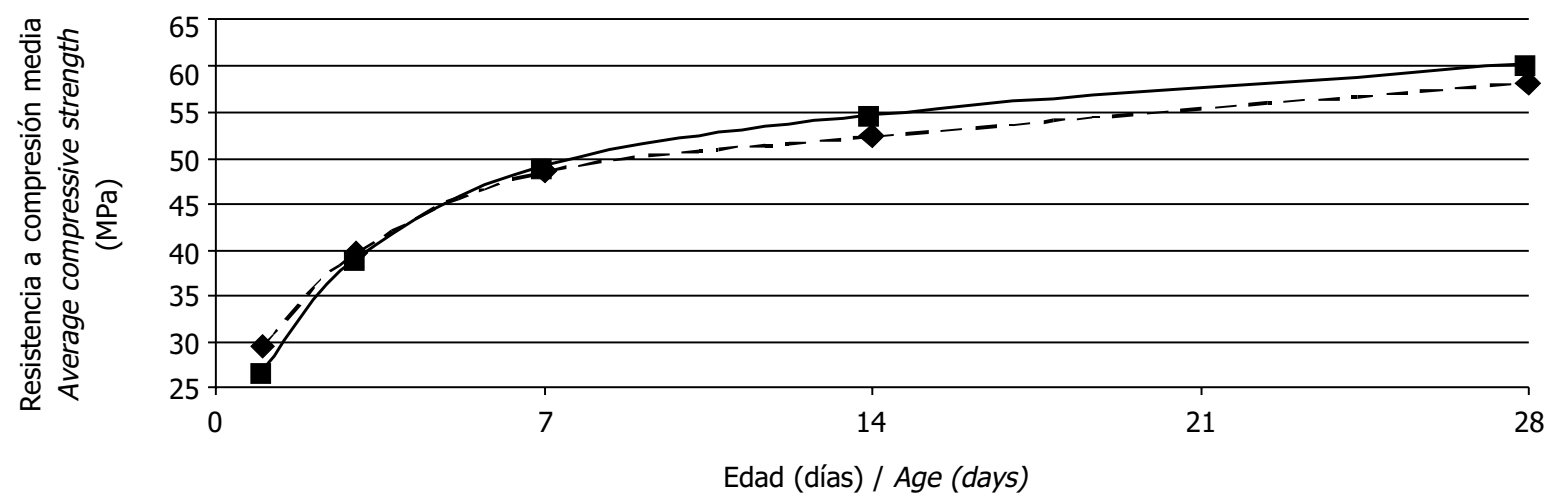

Figura 6. Resistencias mecánicas a compresión de los cementos P y M. Figure 6. Compressive strength of $P$ and $M$ cements. 
inferiores a las del cemento patrón $(P)$. En este intervalo de tiempo, el efecto de sustitución de cemento por adición prevalece sobre el efecto puzolánico. Las resistencias obtenidas a 7, 14 y 28 días de curado evidencian una ligera ganancia de resistencias del cemento $\mathrm{M}$ con respecto al cemento $P$, poniéndose de manifiesto el efecto puzolánico de la adición. A los 28 días de curado, la resistencia alcanzada en el mortero $M$ se incrementó un $3,6 \%$ con respecto al patrón. Estos resultados están totalmente de acuerdo con los datos obtenidos con el ensayo de actividad puzolánica. Con porcentajes mayores de sustitución, Pera et al. (5-8) obtuvieron incrementos en las resistencias a compresión mayores al $10 \%$ de las exhibidas por el cemento de referencia.

A la vista de los resultados obtenidos, el cemento Portland elaborado con la adición procedente de la calcinación del lodo de papel cumple con las especificaciones mecánicas recogidas en la normativa vigente UNE EN 197-1:2000 (12).

\subsection{Tiempo de principio de fraguado y estabilidad en volumen}

La Tabla 6 presenta los resultados obtenidos en la caracterización de las exigencias físicas de los dos cementos seleccionados para el presente estudio.

Con relación al principio de fraguado, el cemento $\mathrm{M}$ exhibe un inicio de fraguado más rápido que el cemento $P$. Las adiciones activas cuando son incorporadas en una matriz de base de cemento, aceleran la hidratación de la alita y de las fases alumínicas presentes en el cemento. Asimismo, la presencia de caliza en los productos calcinados produce una reducción del tiempo de fraguado inicial (17).

Por otro lado, tanto el cemento $\mathrm{P}$ como el cemento $\mathrm{M}$ evidencian un comportamiento análogo en cuanto a la estabilidad en volumen, muy por debajo de los $10 \mathrm{~mm}$ establecidos como límite superior. La adición, por lo tanto, no aporta constituyentes expansivos con respecto al cemento comercial tomado como referencia. substitution of addition for cement prevailed over the pozzolanic effect. The slightly higher values obtained for cement $M$ at 7, 14 and 28 days are consistent with the existence of the pozzolanic effect. After 28 days, strength was $3.6 \%$ higher in mortar $M$ than in the standard. These findings concur with the data obtained with the pozzolanic activity test. Pera et al. (5-8), using larger substitution percentages, obtained compressive strength values $10 \%$ higher in the additioned than in the standard cement.

According to the results obtained, Portland cement manufactured with calcined paper mill sludge additions meets the mechanical strength specifications set out in Spanish/European standard UNE EN 197-1:2000 (12).

\subsection{Initial setting time and volume stability}

Table 6 shows these two physical properties of the cements selected for the present study.

Initial setting time was found to be shorter in cement $M$ than in cement $P$. When included in a cement matrix, active additions accelerate the hydration of the alite and aluminous phases present in the cement. The existence of limestone in calcined products also reduces the initial setting time (17).

Moreover, volume stability was observed to be similar in cement $P$ and cement $M$, with differences much smaller than the 10-mm ceiling. Use of the addition did not, therefore, signify the inclusion of expansive components in the commercial cement taken as a reference.

Tabla 6 / Table 6

Características físicas de los cementos $\mathrm{P}$ y $\mathrm{M}$

Physical properties of cements $P$ and $M$

\begin{tabular}{|l|c|c|}
\hline $\begin{array}{c}\text { Tipo de cemento } \\
\text { Type of cement }\end{array}$ & $\begin{array}{c}\text { Tiempo de principio de fraguado (min) } \\
\text { Initial setting time (min) }\end{array}$ & $\begin{array}{c}\text { Estabilidad de volumen (mm) } \\
\text { Volume stability (mm) }\end{array}$ \\
\hline Cemento P / Cement P & $127.50 \pm 5$ & 0.50 \\
\hline Cemento M / Cement M & $97.50 \pm 5$ & 0.55 \\
\hline Exigencias / Requirements UNE EN 197-1:2000 & $>60 \pm 5$ & $<10$ \\
\hline
\end{tabular}


En cualquier caso, las exigencias físicas de los cementos analizados cumplen los límites establecidos en la normativa vigente UNE EN 197-1:2000.

\subsection{Exigencias químicas}

Los resultados de los contenidos en $\mathrm{SO}_{3}$ y cloruros, así como la pérdida por calcinación de los cementos $\mathrm{P}$ y $\mathrm{M}$, quedan recogidos en la Tabla 7.

El contenido en sulfatos (expresados en $\%$ de $\mathrm{SO}_{3}$ ) en el cemento $\mathrm{M}$ es aproximadamente de un $10 \%$ menor que en el cemento P. Se puede afirmar, por tanto, que la disminución en el porcentaje de $\mathrm{SO}_{3}$ coincide con el porcentaje de sustitución del cemento comercial $\mathrm{P}$ por la adición procedente de la calcinación de los lodos de papel. En este sentido, el lodo calcinado aporta contenidos insignificantes de sulfatos (menor del 0,3\%) con respecto al cemento Portland.

En cuanto al contenido en cloruros, los cementos $\mathrm{P}$ y $\mathrm{M}$ presentan el mismo porcentaje de este tipo de iones. Por lo tanto, la adición incorpora cloruros en su composición en un porcentaje sensiblemente menor a la del cemento P. Es importante señalar que, en ciertos momentos, se pueda disponer de lodos de papel exentos de cloruros, ya que los compuestos clorados no se utilizan en el proceso industrial de la empresa suministradora de los residuos industriales.

Por su parte, el cemento $M$ presenta una pérdida por calcinación un $60 \%$ mayor que el cemento $P$ debido fundamentalmente a la descarbonatación de la calcita contenida en la adición dado que, entre $700{ }^{\circ} \mathrm{C}$ y la temperatura de $975{ }^{\circ} \mathrm{C}$ recogida en norma para cuantificar este parámetro en cementos comerciales, se produce el proceso de transformación de la calcita a cal libre ( $\mathrm{CaO})$.

Por lo tanto, a la vista de los resultados obtenidos, se puede afirmar que el nuevo cemento que incorpora la adición procedente de la calcinación del lodo de destintado del papel se ajusta a las exigencias químicas establecidas en la normativa vigente UNE EN 197-1:2000.
In any event, the cements analyzed met the setting time and stability requirements laid down in Spanish/European standard UNE EN 197-1:2000, presently in force.

\subsection{Chemical requirements}

Table 7 contains the $\mathrm{SO}_{3}$ and chloride content, as well as the loss on ignition values for cements $P$ and $M$.

The sulphate content (expressed in $\%$ of $\mathrm{SO}_{3}$ ) was approximately $10 \%$ lower in cement $M$ than cement $P$. The decline in the percentage of $\mathrm{SO}_{3}$ concurred, therefore, with the percentage commercial cement $P$ replaced by calcined paper mill sludge in the blend. In other words, the addition was responsible for only an insignificant amount of the total sulphate content in the blended cement (under 0.3\%).

Since cements $P$ and $M$ had the same chloride ion content, the addition must have a substantially smaller percentage of chlorides in its composition than cement $P$. It should be stressed that chloride-free paper mill sludge may be available in certain cases: the supplier of the industrial waste for the present study, for instance, does not use chlorinated compounds in its industrial processes.

Cement $M$ in turn has a $60 \%$ higher loss on ignition than cement $P$, due essentially to the decarbonation of the calcite in the addition, for this mineral is transformed into free lime $(\mathrm{CaO})$ in the 700 to $975^{\circ} \mathrm{C}$ temperature range specified in the standard to quantify this parameter in commercial cements.

Therefore, according to the results obtained, the new cement manufactured with a calcined paper mill sludge addition is UNE EN 197-1:2000 compliant.

Tabla 7 / Table 7

Características químicas de los cementos $\mathrm{P}$ y $\mathrm{M}$

Cement $P$ and $M$ chemistry

\begin{tabular}{|l|c|c|c|}
\hline Tipo de cemento / Type of cement & SO $_{\mathbf{3}}(\%)$ & Cl (\%) & PF (\%) \\
\hline Cemento P / Cement P & 3.20 & 0.028 & 2.57 \\
\hline Cemento M / Cement M & 2.89 & 0.028 & 4.13 \\
\hline Exigencias / Requirements UNE EN 197-1:2000 & $<4$ & $<0.10$ & $<5 \%$ \\
\hline
\end{tabular}




\section{CONCLUSIONES}

Las principales conclusiones derivadas del presente estudio se exponen a continuación:

- Las condiciones de calcinación influyen directamente sobre la actividad puzolánica de la nueva adición. La mayor actividad puzolánica se obtiene bajo unas condiciones de calcinación de $700{ }^{\circ} \mathrm{C}$ durante 2 horas de tratamiento.

- La incorporación de un $10 \%$ de lodo de papel calcinado a una pasta de cemento modifica ligeramente el principio de fraguado del cemento, acelerando el proceso en 30 minutos, no supone inestabilidad de volumen e incrementa levemente las resistencias a compresión a partir de los 7 días de curado.

- El cemento con un $10 \%$ de lodo de papel calcinado presenta valores químicos para los sulfatos y cloruros similares al cemento de referencia y algo superior en el valor de pérdida por calcinación debido a la presencia de caliza en la adición puzolánica.

Como resumen de todo lo expuesto en el presente trabajo, se puede deducir que la incorporación de una adición objeto de estudio en la fabricación de cementos es viable, dado que las matrices cementantes con este tipo de adición cumplen con las exigencias químicas, físicas y mecánicas recogidas en la normativa vigente.

\section{AGRADECIMIENTOS}

Los autores del presente trabajo quieren agradecer al Ministerio de Educación y Ciencia del Gobierno Español por los fondos subvencionados en el presente proyecto de investigación (MAT2003-06479-C03). Asimismo, agradecen la colaboración de la empresa Holmen Paper/Papelera Peninsular, S.L. por el suministro de los lodos a partir de los cuales se ha obtenido la adición puzolánica.

\section{CONCLUSIONS}

The main conclusions drawn from the present study are listed below:

- Calcination conditions have a direct effect on the pozzolanic activity of the new addition. Pozzolanic reactivity was highest when the material was calcined at $700^{\circ} \mathrm{C}$ for two hours.

- The inclusion of calcined paper sludge in a cement paste at a rate of $10 \%$ modifies initial cement setting time slightly, accelerating the process by 30 minutes; such additions exhibit good volume stability and enhance compressive strength to a certain extent after 7 days of curing.

- Sulphate and chloride content values in cement containing $10 \%$ calcined paper mill sludge are similar to the values for the reference cement, whereas loss on ignition is higher in the former due to the presence of limestone in the pozzolanic addition.

By way of summary of the foregoing, it may be deduced that the inclusion in cement of additions such as those addressed in this study is feasible, inasmuch as the cementitious matrices containing such additions are compliant with the chemical, physical and mechanical requirements set out in the existing standards.

\section{ACKNOWLEDGEMENTS}

The present study was funded by the Spanish Ministry of Education and Science under research project (MAT2003-06479-C03). The authors wish to thank Holmen Paper/Papelera Peninsular, S.L. for supplying the sludge from which the pozzolanic addition was obtained.

\section{BIBLIOGRAFÍA/BIBLIOGRAPHY}

(1) Horton, R.: "Factor Ten Emisión Reductions: The Key to Sustainable Development and Economic Prosperity for the Cement and Concrete Industry", $3^{\text {rd }}$ CANMET/ACI International Symposium on Sustainable Development of Cement and Concrete. Ed. V. M. Malhotra, ACI SP-202, San Francisco, USA (2001), pp. 1-14.

(2) Frías, M., Sánchez de Rojas, M. I., Menéndez, I., Cristina, C. y García de Lomas, M.: "Propiedades de la escocia Si-Mn como material puzolánico en la fabricación de cementos Portland", Mater. Construcc., vol. 55, no 280 (2005), pp. 1-9.

(3) Villar Cociña, E., Frías, M., Valencia, E. y Sánchez de Rojas, M. I.: "Validación de un modelo cinético-difusivo para caracterizar la cinética de reacción puzolánica en sistemas ceniza de paja de caña-arcilla-cal", Mater. Construcc., vol. 55, nº 278 (2005), pp. 29-40.

(4) Frías, M., Sánchez de Rojas, M. I.: "Influence of metastable hydrated phases on the pore size distribution and degree of hydration of MK-blended cements cured at $60{ }^{\circ} \mathrm{C}^{\prime \prime}$, Cem. Concr. Res., 35 (2005), pp. 1292-1298.

(5) Pera, J. y Ambroise, J.: "Pozzolanic properties of calcined paper sludge", Proceedings of the $11^{\text {th }}$ International Congress on the Chemistry of Cement. (2003), pp. 1351-1360.

(6) Pera, J., Ambroise, J. y Chabannet, M.: "Transformation of wastes into complementary cementing materials", 7 th International Conference on fly ash, silica fume, slag and natural pozzolans in concrete. Ed. V. M. Malhotra, ACI SP-26, vol. II, Chennai, India (2001), pp. 459-475. 
(7) Pera, J. y Amrouz, A.: "Development of highly reactive metakaolin from paper sludge", Advanced Cement Based Materials, 7 (1998), pp. 49-56.

(8) Pera, J. y Ambroise, J.: "Calcined paper sludge: an interesting admixture for the cement industry", Proceedings of the Sidney Diamond Symposium-Materials Science of Concrete. Ed. M. Cohen et al. (1998). pp. 467-479.

(9) Frías, M., Sánchez de Rojas, M. I. y Rivera, J.: "Influence of calcining conditions on pozzolanic activity and reaction kinetics in paper sludge-calcium hydroxide mixes", $8^{\text {th }}$ CANMET/ACI International Conference on fly ash, silica fume, slag and natural pozzolans in concrete. Ed. V. M. Malhotra (2004), pp. 879-892.

(10) Rodríguez, O., Frías, M., Sánchez de Rojas, M. I. y Menéndez, I.: "Viabilidad de la incorporación de lodos de papel al cemento como adición puzolánica", VI Congreso Nacional de Materiales Compuestos, UPV (Ed.), vol. 1 (2005), Valencia, España, pp. 917-923.

(11) Confederation of European Paper Industries (CEPI) and the International Confederation of Paper and Board Converters in Europe (CITPA). Towards a Thematic Strategy on Prevention and Recycling of Waste Paper and board manufacturing and converting industry's position (2003).

(12) Schultz, L. G.: "Quantitative interpretation of the mineralogical composition from X-ray and Chemical data for the Pierre Shale. U. S. Geol. Surv. Prof. Pap. (1964), 391 C, 31 pp.

(13) Barahona, E.: Arcillas de ladrillería de la provincia de Granada. Evaluación de algunos ensayos en materias primas. Tesis Doctoral, Universidad de Granada, 1964, 398 pp.

(14) Brindley, G. W.: "Order-Disorder in Clay Minerals Structure", en G. W. Bridley y G. Brown (eds.): Cristal Structures of Clays Minerals and their X-Ray identification. Mineralogical Society Monograph 5. Londres, 1980, p. 496.

(15) Frías, M., Sánchez de Rojas, M. I., Rodriguez, O., García, R. y Vigil, R.: "Characterization of calcined paper sludge as environmentally-friendly source of MK for manufacturing of cementing matrixes", Cem. Concr. Res, under review (2005).

(16) UNE-EN 197-1, Cemento. Parte 1: Composición, especificaciones y criterios de conformidad de los cementos comunes, 2000.

(17) Taylor, H. F. W.: Cement Chemistry. Thomas Telford Publishing, Tomas Telford Services Ltd, 2a Edición, Londres, 1997, p. 436. 